\title{
Forest-water interactions in the changing environment of south-western Australia
}

\author{
Richard Harper ${ }^{1}$ (D) K. R. J. Smettem ${ }^{1} \cdot$ J. K. Ruprecht ${ }^{1} \cdot$ B. Dell ${ }^{1} \cdot$ Ning Liu $^{1}$
}

Received: 31 August 2018 / Accepted: 27 August 2019 / Published online: 17 October 2019

(C) INRA and Springer-Verlag France SAS, part of Springer Nature 2019

\begin{abstract}
- Key message In a major Australian city, water supply has been decoupled from forests as a result of management and climate change. Water yield and quality are closely related to forest cover and have been manipulated through broadscale intervention. The forests remain important for biodiversity protection and considering water as a forest product will fund interventions that maintain the forest's environmental values.

- Context Perth, an Australian city of 2 million people and a potable water demand of $300 \mathrm{GL} / \mathrm{year}$, occurs in a region that has experienced a decline in rainfall and a major reduction in surface runoff to water supply reservoirs over the last 40 years. This has led to a major impact on water policies, with the collapse of surface water supply from forested watersheds resulting in the almost complete substitution of Perth's water supply with groundwater and desalinated water. Thus, water supply has been decoupled from forests and forest management processes.

- Aims In this paper, we review the interactions between forest cover and water supply in the drying environment of southwestern Australia, exploring studies on the hydrological effects of extensive deforestation for agricultural development, widespread reforestation, forest management, and reduced annual rainfall. We draw conclusions applicable to other regions that are experiencing the combined impacts of climate change and pressures from land-use intensification.

- Results We find that streamflow and water quality are clearly linked to forest cover and this is affected by both climate and forest management. Streamflow increases with a reduction of forest cover (through deforestation or thinning) and decreases with reforestation and reduced rainfall. Stream salinity increases with deforestation and decreases with reforestation. Hydrological responses occur where forest cover treatments have been applied and maintained at watershed-scales. Surprisingly, where water yield or quality has been improved, this has not been rewarded financially and there is a need to develop methods of financing treatments to maintain streamflow.

- Conclusion Whereas forests were initially maintained for water and timber supply, with biodiversity protection as a co-benefit without a defined value, the decoupling of forests from water supply has substantially reduced the financial resources for any form of direct forest management. As the forests remain important for biodiversity protection, a key recommendation is to consider water as a forest product and thus provide funds for watershed-scale treatments, such as forest thinning, that maintain the forest's environmental values in a drying climate.
\end{abstract}

Keywords Forest management $\cdot$ Australia $\cdot$ Climate change $\cdot$ Water yield $\cdot$ Payment for environmental services

This article is part of the topical collection on Forest Adaptation and Restoration under Global Change

Handling Editor: Andreas Bolte

Contributions of the co-authors The authors contributed equally to the writing of the paper.

Richard Harper

R.Harper@murdoch.edu.au

1 Agricultural Sciences, Murdoch University, Murdoch 6150, WA, Australia

\section{Introduction}

In many regions of the world, several major stressors on forest-water interactions are becoming apparent. These include changes in land use as a consequence of increasing population and climate change with its multiple elements of changed water balance and extremes of temperature (IPCC 2012; IPCC 2013). Climate change has direct impacts on forests (Allen et al. 2010), water yield (Milly et al. 2005), and fire frequency and intensity (Giglio et al. 2013). Dramatic decreases in streamflow have been observed in 
most areas with Mediterranean climates due to climate change and land cover change (Little et al. 2009; Lutz et al. 2016; Peñuelas et al. 2017). Moreover, most climate models forecast an increase in temperature and a decrease in precipitation at the end of the twenty-first century in Mediterranean areas (Garcia-Ruiz et al. 2011), which may further enlarge the deficit between the water supply and the water demand from irrigated and urban areas.

South-western Australia provides clear examples of how these multiple stressors affect the forest-water interface in a drying climate and how different management responses have been developed to counteract them. Water for the urban population of south-western Australia was traditionally sourced from forested watersheds, but in the last four decades, streamflow has effectively declined to the point where inflows to impoundments, in many years, simply meet their evaporative losses. Water for public use is now primarily sourced from both groundwater and desalination of seawater and this is expected to continue into the future as water demand increases with ongoing population growth (Water Corporation 2015). The reservoirs that were a dominant source of water for Perth are now being used primarily as storages for climateindependent, desalinized water produced during periods of low urban water demand (Water Corporation 2015). However, in wet years, if they occur, water inflows to reservoirs will be used for urban water supply.

This change in water supply has been caused by a range of pressures that are also experienced or evolving in or near urban conurbations elsewhere in the world. These include increasing population and demand for water, land-use change, and climate change. In south-western Australia, these pressures have led to extensive studies on forest-water interactions in order to devise new management strategies. The insights and understanding gained in this environment may benefit other regions also experiencing similar pressures.

In this paper, we thus review a series of studies that have examined the interactions of forests and surface water, and in particular the reasons for the profound change in water balance. Several authors have suggested that changes in water yield are related to climate change (Bates et al. 2008; Silberstein et al. 2012), however, they are also likely due to the imprint of past forest management (Li et al. 2010; Liu et al. 2019) and we discuss the implications of this for the future eco-hydrological status of the forested watersheds. Several examples of forest and water interactions in this region are considered with regard to consequences in terms of water yield, quality, and management response options. These examples encompass differences in forest cover and thus water balance at scales ranging from local plot to watershed as a result of: (1) extensive deforestation for agricultural development and subsequent reforestation, (2) changes in climate such as increased temperatures and reduced annual rainfall, and (3) changes in evapotranspiration due to forest management interventions such as forest thinning and timber harvesting.

Finally, we examine the broader question of what happens when forests and water supply are decoupled in the water supply of a major city. The reason that intact forests occur close to a major city in this region is primarily for their value in both producing timber and protecting water quality (Dell et al. 1989). However, these reasons no longer exist and so we attempt to answer the question of what is likely to happen when water supply is no longer the main motivation for retaining forests, or in other terms the economic value of forest water has been diminished to zero.

\section{Setting the scene: climate, soils, hydro-geology, and land-use}

\subsection{Climate and climate change}

Although the farmed region of south-western Australia extends into areas with annual rainfall of $300 \mathrm{~mm} /$ year, most freshwater resources occur in the Northern Jarrah Forest with rainfall of 600-1400 mm/year (Fig. 1). Most of Western Australia's population also occurs in this latter region, and is particularly concentrated in the capital Perth, with 2.02 million people or 78\% of the Western Australia's total (ABS 2016). In this paper, we thus focus on the Northern Jarrah Forest which encompasses an area of $40,000 \mathrm{~km}^{2}$ and concentrate on management that has occurred in the last 100 years.

This region has a Mediterranean climate, with $80 \%$ of rainfall falling between May and October with this decreasing systematically inland. Pan evaporation generally increases along a south-north gradient, from $1400 \mathrm{~mm} /$ year in the south to $1800 \mathrm{~mm} /$ year in the north (Bureau of Meteorology 2018).

Across the region, a systematic decrease in rainfall of 15$20 \%$ since the mid-1970s was reported by Bates et al. (2008) and this has been subsequently maintained. Much of the reduction in rainfall has occurred over the early winter months of May to July and this has been accompanied by the cessation of very high rainfall years which were previously common (Bates et al. 2008). Figure 2 shows the long-term (19352017) annual rainfall for two rainfall stations in close proximity to surface watersheds and the long-term mean rainfalls before and after a 1975 changepoint (Liu et al. 2019). For these stations, it is clear that a decline in rainfall has continued. The decrease in annual rainfall in 1975-2017 ranged from $151 \mathrm{~mm}$ or $16 \%$ for Collie to $161 \mathrm{~mm}$ or $12 \%$ for Dwellingup compared to the pre-change (1935-1974) mean.

There has also been a mean maximum temperature change of around $1{ }^{\circ} \mathrm{C}$ (Silberstein et al. 2012) through the twentieth century. Climate change projections are both emission scenario and model-dependent, however, two studies that evaluated several climate models with different emission scenarios were 


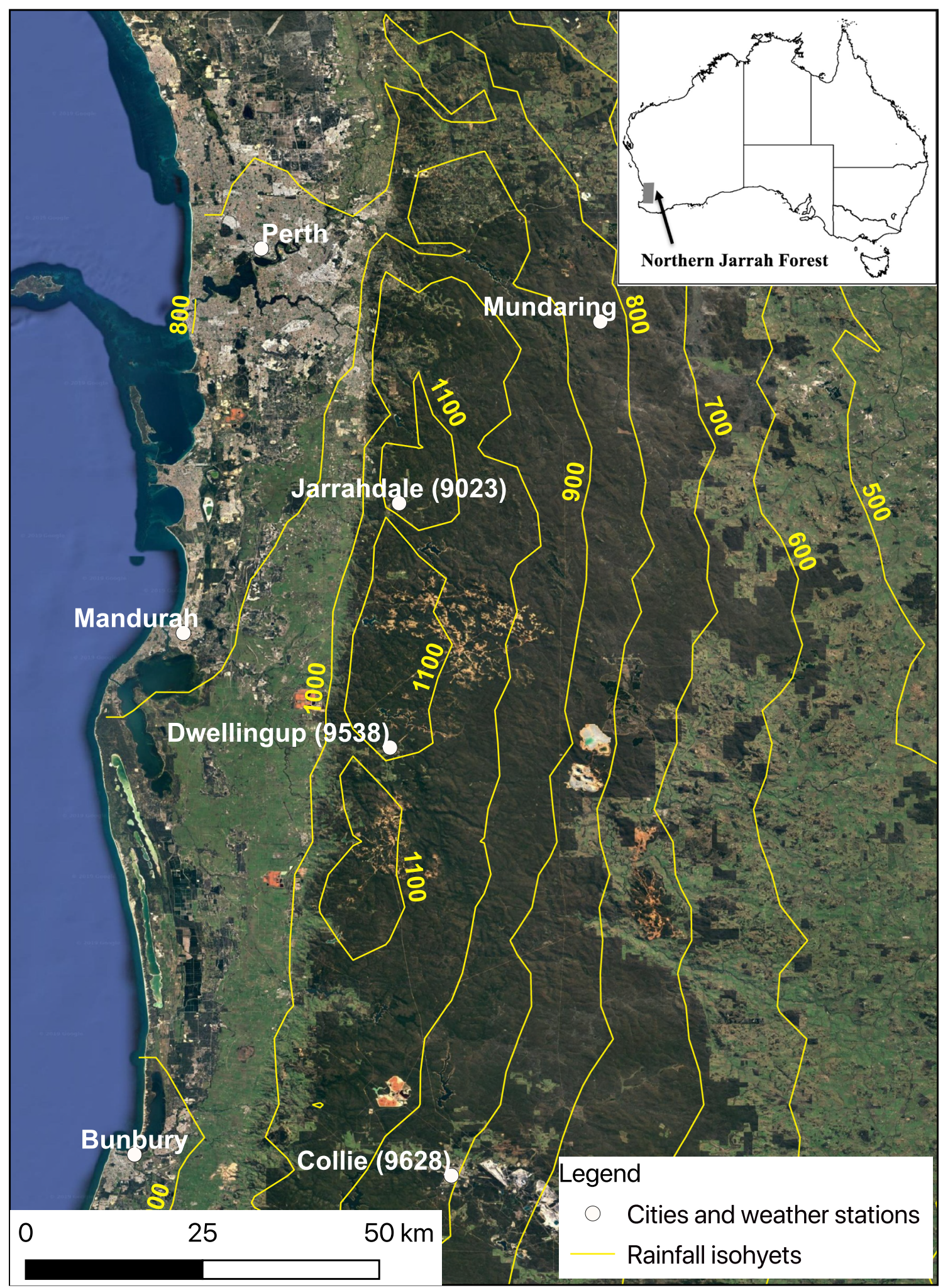

Fig. 1 Map showing rainfall isohyets (historical climate from 1961 to 1990) with the Northern Jarrah Forest (dark green) in the background. The light green areas are deforested farmland. (source: ESRI, Digital

consistent in terms of predicting decreased rainfall and increasing mean temperatures (Bates et al. 2008; Silberstein
Globe, GeoEye, Earthstar Geographics, CNES/Airbus DS, USDA, USGS, AeroGRID, IGN and the GIS User Community)

et al. 2012). These changes will in turn affect the overall water balance, forest growth, and water yields. 
Fig. 2 Annual rainfall (mm/year) for two rainfall stations (Dwellingup (•) and Collie (०) that are in close proximity to surface water reservoirs. Mean rainfall for the periods before and after the change point (1975) are also presented, along with the overall decline (\%) (Data from Australian Bureau of Meteorology)

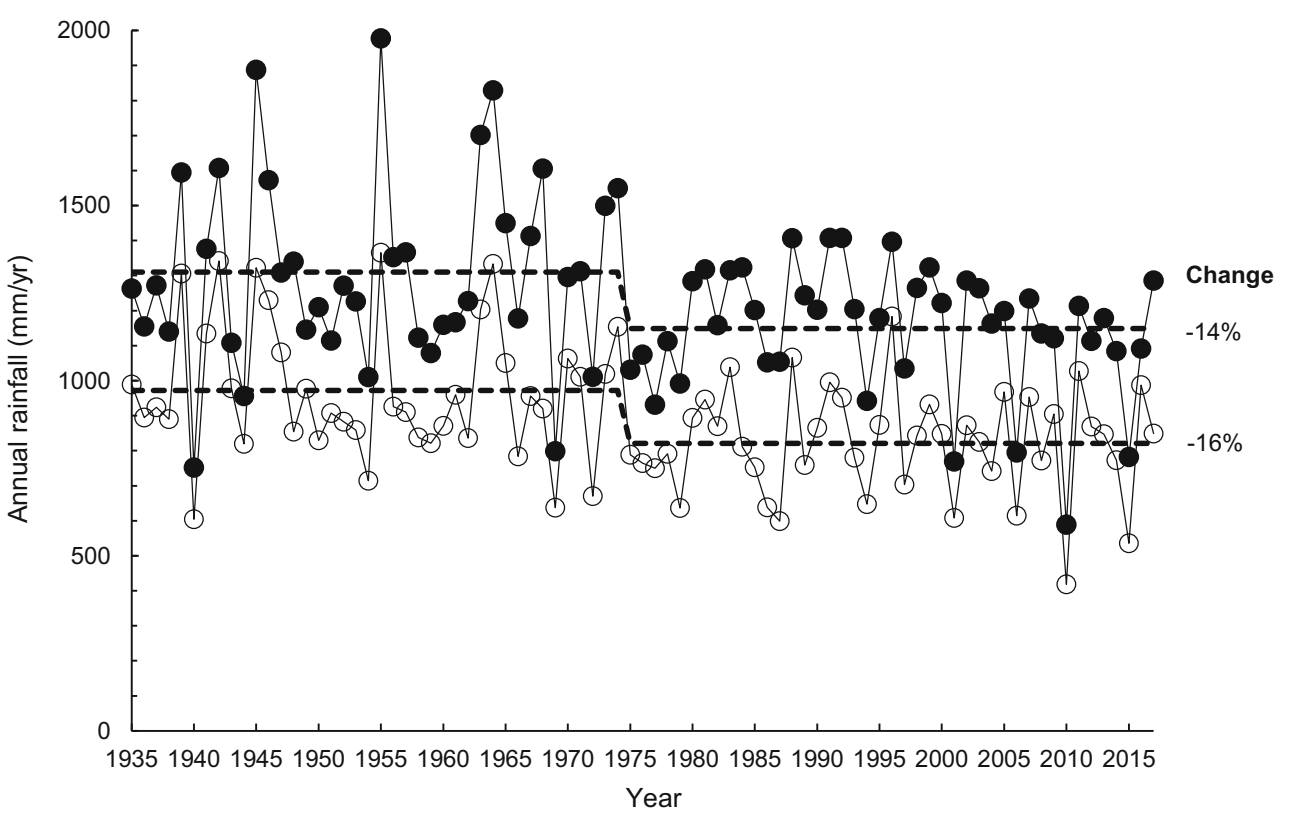

\subsection{Change in water demand and sources of supply}

Perth's water supply has two main components: "public water" supplied for households and industry by the Water Corporation, a government trading enterprise; and "private water" which is predominantly comprised of groundwater from near surface aquifers and is used for horticulture, irrigation of public parks and gardens, private gardens, and industry (Water Corporation 2009). Supply of both sources is regulated by the Western Australian Government's Department of Water and Environmental Regulation.

There has been rapid population growth and changes in potable water demand across the region (Fig. 3). In 1950, Perth's population was 0.3 million, with water usage of $59 \mathrm{GL} /$ year, almost exclusively derived from forested surface watersheds. In 1979, following a severe drought, groundwater

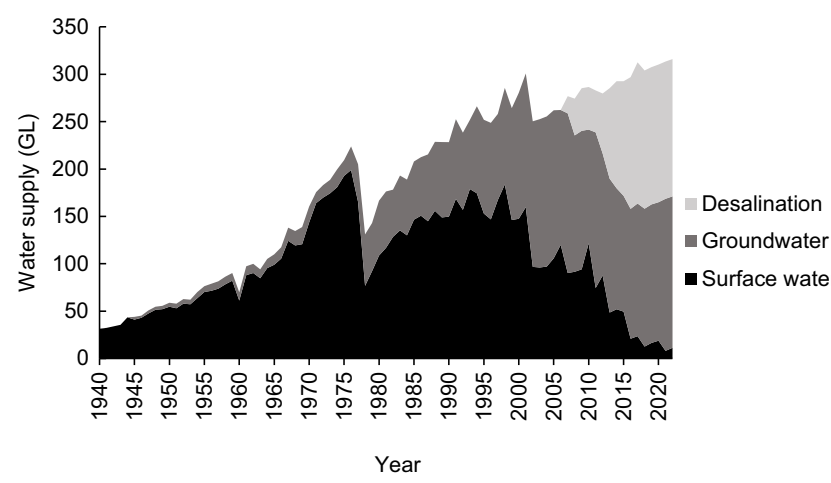

Fig. 3 The observed (1940-2014) and estimated (2014-2023) public water supply for Perth, adapted from Bennett and Gardner (2014). Streamflow in forested watersheds has collapsed and has been replaced by groundwater and desalination. Groundwater includes managed aquifer recharge from treated wastewater from 2018 onwards resources were developed (McFarlane et al. 2012b), such that by 1990 the then population of 1.15 million obtained water from surface $(150 \mathrm{GL} /$ year, $66 \%)$ and groundwater sources (79 GL/year, 34\%).

Climate change analysis performed in the late 1980s predicted a decline in rainfall and a reduction in streamflow of $45 \%$ (Sadler et al. 1988). In response, the Western Australian Government implemented a program of both increased groundwater use and seawater desalination. In the latter case, two plants now produce $150 \mathrm{GL} /$ year of desalinated water. In 2014/2015, the public water supply for Perth, Mandurah, Goldfields, and inland agricultural areas (termed the Integrated Water Supply Scheme or IWSS) was 291 GL/year with private water supply, mainly derived from groundwater, comprising a further $370 \mathrm{GL} /$ year (Water Corporation 2015). Groundwater and seawater desalination are now the dominant public water sources.

Perth's population is projected to increase to 3.5 million by 2050 (Western Australian Planning Commission 2015) and public water demand may increase to around $470 \mathrm{GL} /$ year (Water Corporation 2009). The Water Corporation (2009) proposes that the gap between supply and demand will be met by groundwater and desalination with the surface water reservoirs being relegated to a role for water storage for excess desalination.

\subsection{Regolith and hydrogeology}

The Northern Jarrah Forest is located on regolith formed from the granites and gneisses of the Archaean Yilgarn Craton (Myers 1990). The Yilgarn Craton was intensively weathered, possibly in the Miocene, such that primary minerals were converted to kaolinitic clays and iron and aluminum oxides (Anand and Paine 2002) to depths up 30 to $>100 \mathrm{~m}$ (Taylor 
and Butt 1998). This weathering mantle has been stripped away along drainage lines, with a resultant pattern of relatively fertile, shallow soils along the river valleys and infertile, deep soils in the interfluves (Harper et al. 2009). Some valleys have not been stripped and contain sediments (McArthur 1991).

The deep regolith has localized aquifer systems, both at the base of the regolith, within valley in-fill sediments, and also within cracks and fissures within the basement geology. The regolith thus has both saturated and unsaturated zones. In higher rainfall (> $800 \mathrm{~mm} /$ year) areas, groundwater in the saturated zone discharges to streams in the valley floor. In these situations, the unsaturated zone is absent, whereas it may be $20 \mathrm{~m}$ deep in upper slope areas. In lower rainfall $(<800 \mathrm{~mm} /$ year) areas, the deep groundwater tables are far below the stream bed and do not contribute to streamflow, and consequently, the regolith is dominated by the unsaturated zone.

Highly permeable soils are widespread across the Yilgarn Craton and combine with generally low storm rainfall intensities to restrict the occurrence of saturation excess runoff to saturated areas close to streams (Ruprecht and Schofield 1989). These saturated areas are supplied from upslope by throughflow (Williamson et al. 1987), creating a lag in the onset of runoff to initial winter rainfall as soil moisture stores require replenishment before a connection is established between hillslope percolation and riparian zones. In a drying climate, this runoff lag is increasing with many streams that were permanent now becoming ephemeral (Petrone et al. 2010; Smettem et al. 2013).

These regolith aquifer systems are however not used for water supply. The aquifers that supply Perth's water are physically separate from the Yilgarn Craton, occurring within the sedimentary Perth Basin, which is immediately to the west and have no hydrogeological connection with the surface watersheds.

\subsection{Forests, forest management, and land-use change}

There was complete forest cover in this region at the time of European settlement in 1829 (Dell et al. 1989). After settlement, there was considerable forest harvesting and deforestation for agriculture and urban purposes. Around $30,000 \mathrm{~km}^{2}$ of land still has natural vegetation with $24,000 \mathrm{~km}^{2}$ of forest, with $81 \%$ of this vested with the Western Australian Government (Conservation Commission of Western Australia 2013, p.8) and the remainder in private ownership.

The forests on the Yilgarn Craton in the Perth region are dominated by Eucalyptus marginata, or jarrah, this forming a 30-40-m tall evergreen forest with a diverse understorey (Dell et al. 1989). Almost all of the larger jarrah has been harvested, with a rotation length of 50 to 200 years (Stoneman et al. 1989), and consequently, the forest is now almost wholly comprised of regrowth of various ages. Low-intensity fires are used at intervals of 6 to 8 years to reduce the build-up of fuel loads (McCaw and Burrows 1989) and prevent wildfires. Current forestry practice involves selective logging rather than clear-fall, with 135 to $185 \mathrm{~km}^{2}$ harvested annually (Conservation Commission of Western Australia 2013). In response to vigorous public debates about the merits of logging natural forests, $62 \%$ of the forest has been placed in conservation reserves (Conservation Commission of Western Australia 2013).

Approximately $10 \mathrm{~km}^{2} /$ year of jarrah forest is also deforested for bauxite, gold, and coal mining (Conservation Commission of Western Australia 2013), with around $180 \mathrm{~km}^{2}$ cleared and rehabilitated to date. The principal bauxite lease area covers $50-60 \%$ of the Northern Jarrah Forest, including most of the water supply watersheds for Perth. The mined areas are typically rehabilitated with forest species representative of the previous forest type (Koch and Hobbs 2007).

\subsection{Salinity and land-use}

The regolith on the Yilgarn craton contains salt stores that have accumulated from incoming rainfall over long periods (Hingston and Gailitis 1976), and because of the depth of the regolith, these salt stores can be substantial. Salt storage has been reported to range from 4 to $20 \mathrm{~kg} / \mathrm{m}^{2}$ with this increasing systematically with decreasing rainfall (Johnstone 1981; Tsykin and Slessar 1985).

The root systems of the natural forest have been reported to extend to depths of at least $40 \mathrm{~m}$ (Dell et al. 1983), and in this situation, deeper salt stores are effectively disconnected from the surface waters. Removal of deep-rooted forests and replacement with shallow-rooted annual crop and pasture plants changes the water balance, with increased recharge leading to groundwater rise in valleys and widespread salt discharge into streamlines and the ground surface (Ruprecht and Schofield 1991).

Although several watersheds with reservoirs have remained wholly forested, there are some that have been partially deforested. In every case where this has occurred, stream salinity has increased (Bari and Ruprecht 2003; Hatton et al. 2003) and has thus compromised water quality in reservoirs. For example, the $1480 \mathrm{~km}^{2}$ Helena watershed near Mundaring has $3 \%$ deforestation and salinity of $510 \mathrm{mg} / \mathrm{L}$ total dissolved solids (TDS) (Smith et al. 2007) and the $2827 \mathrm{~km}^{2}$ Collie watershed has had $19 \%$ deforestation and salinity of 945 mg/L TDS (Mauger et al. 2001). The TDS threshold for human usage based on esthetics is $500 \mathrm{mg} / \mathrm{L}$ (National Health and Medical Research Council 2004).

\section{Impacts of management and climate change on forests and water}

There have been strong hydrological responses in the Yilgarn Craton to deforestation and reforestation in terms of both 
streamflow and stream salinity (Peck and Williamson, 1987; Ruprecht and Schofield 1989; Bari and Ruprecht 2003; Peck and Hatton 2003). In all cases, the level of response depends on the amount of cover change and watershed characteristics (Liu et al. 2019). Additionally, a significant decline in rainfall has been observed since 1975, and this has resulted in a dramatic decrease in streamflow into Perth reservoirs (Petrone et al. 2010). As described earlier, south-western Australia has a Mediterranean climate, with an annual summer drought. Superimposed on this pattern is annual variability with periodic droughts, with these being associated with mortality in Eucalyptus plantations (Harper et al. 2009) and natural forests (Matusick et al. 2013; Walden et al. 2019).

\subsection{Impacts of forest management on water}

Although there were early reports of the deterioration of water quality following deforestation and its restoration following reforestation in the Helena River watershed (Wood 1924), there was considerable debate from that time onwards (e.g., see Western Australian Parliamentary debates in 1976) whether there was, in fact, a direct cause and effect relationship between deforestation and stream salinity, and thus what the management responses should be.

This was during a period of rapid alienation, or freeholding, of forested Crown land and subsequent deforestation for agriculture (Burvill 1979) with agricultural development mostly having precedence over water supply (Smith 1950). In 1961, an administrative decision was made to suspend further releases of forested Crown land for agriculture and in 1964 a Parliamentary Committee unsuccessfully recommended that deforestation controls be instituted on already alienated land. Over the next decade, the debates continued until the Country Areas Water Supply Act 1947 was amended (Country Areas Water Supply Act Amendment Act 1976; Country Areas Water Supply Act Amendment Act 1978) to limit agriculturally induced deforestation in water supply watersheds and thus prevent stream salinization. Several paired watershed studies were also established in the Collie watershed from 1969 (Peck and Williamson, 1987) to investigate the impact of deforestation on runoff and stream salinity.

As an example of the responses that occur with deforestation and reforestation, the Denmark watershed $\left(502 \mathrm{~km}^{2}\right)$ was partially (20\%) deforested from the late 1940s onwards, and stream salinity and total salt-load and total streamflow increased (Fig. 4) (Bari et al. 2004; Ruprecht et al. 2019). This was consistent with the results from chloride balance studies (Peck and Hurle 1973) and the results from deforestation experiments in smaller $\left(0.8-3.5 \mathrm{~km}^{2}\right)$ experimental watersheds (Peck and Williamson, 1987; Bari and Ruprecht 2003).

Just as there had been conjecture about the causes of salinity, there was also conjecture about how to reverse its effects. The State Salinity Strategy (1996) outlined potential management responses and these broadly related to the manipulation of watershed water balances or the capture and diversion of saline waters into disposal areas. Water balance approaches included increasing water use through reforestation or the use of deep-rooted pasture plants and protecting existing forest cover.

In the late 1980s, an agroforestry approach with strips of pulpwood eucalypts interspersed with agricultural crops and pastures was advocated (Ruprecht et al. 1985; Shea and Bartle 1988; Bartle and Shea 1989). The underlying plan was for the forestry investment to be financially self-sustaining, with this providing a water quality co-benefit. Despite suggestions that stream salinity could be restored by only partially reforesting landscapes, this was subsequently discounted (George et al. 1999). Similarly, there were other indications that almost complete forest cover was required to either restore or maintain stream water quality. For example, although the Helena watershed was only $3 \%$ deforested there was a continuing efflux of salt from the deforested land into the river and reservoir (Croton and Dalton 1999; Smith et al.
Fig. 4 Change in salinity $(\mathrm{mg} / \mathrm{L}$ TDS) in the $502 \mathrm{~km}^{2}$ Denmark River watershed (Mt Lindesay gauging station) following deforestation and reforestation. Deforestation commenced in the late 1940s with deforestation controls imposed in 1978 (I) when $20 \%$ of the watershed was deforested. Reforestation commenced in 1988 (II) with 5\% now deforested. The dotted line is the target stream salinity of $500 \mathrm{mg} / \mathrm{L}$ TDS. Adapted from Ruprecht et al. (2019)

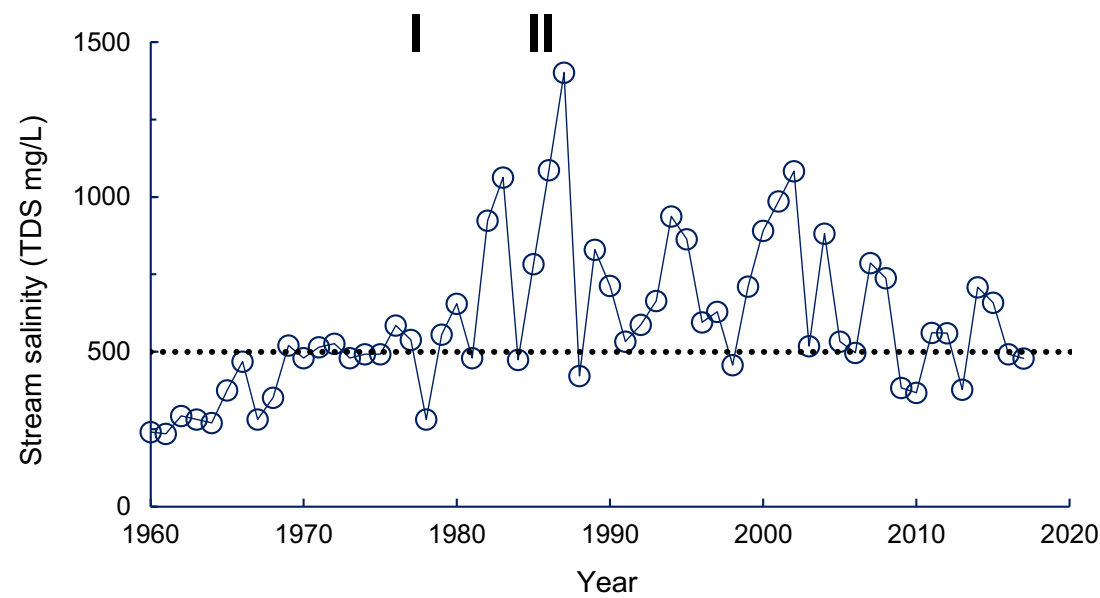


2007). Issues with obtaining widespread reforestation are related to the costs of achieving this and the displacement of agricultural activity and rural communities (Harper et al. 2012; Harper et al. 2017).

In the case of the Denmark River watershed, widespread reforestation was possibly achieved inadvertently. For a variety of reasons, investment in pulpwood forestry rapidly expanded across southern Australia in the period up to 2007 (Parsons and Gavran 2010) and plantation companies reforested whole landscapes rather than managing agroforestry plantings. Consequently, in watersheds such as the Denmark there was almost complete reforestation and stream salinity and salt outflows have subsequently reduced (Fig. 4) and are likely to revert to pre-deforestation values (Ruprecht et al. 2019). Although overall water flows have also reduced, this water is now of a quality that can be utilized as a potable supply. Modeling across several other partially deforested watersheds has suggested similar improvements in water quality are possible with reforestation (Mauger et al. 2001; Bari and Ruprecht 2003; Bari and Smettem 2006; Smith et al. 2006; Smith et al. 2007).

Apart from deforestation and reforestation, forest thinning was considered likely to increase streamflow by reducing forest canopy interception (Stoneman and Schofield 1989), with widespread intervention posited to produce $48 \mathrm{GL} /$ year of additional flow in existing dammed watersheds. This followed earlier work that reported responses in groundwater levels and streamflow from logging (Stokes and Batini 1985).

Several watershed-scale thinning experiments were established in the 1980s (Ruprecht and Stoneman 1993; Stoneman 1993; Bari and Ruprecht 2003). Forest thinning generally resulted in an initial increase in streamflow followed by a return to pre-disturbance levels. However, the return to pre-disturbance levels can be delayed by regrowth suppression at the time of the initial thinning or through later regrowth control. For example, the uniform, intensive thinning treatment in Hansen watershed (annual rainfall $1200 \mathrm{~mm} /$ year) reduced crown cover from 60 to $14 \%$, which resulted in an increase in streamflow of approximately $20 \%$ of annual rainfall (260 mm/year) after 3 years (Ruprecht et al. 1991). Stoneman (1993) found an increase of $86 \mathrm{~mm}$ (7\% of annual rainfall) in water yield, 9 years after the thinning of Yarragil $4 \mathrm{~L}$ forest watershed. However, there is still no consistent result on the effects of land cover change on water yield; it depends on the amount of cover change and watershed characteristics. For example, although $64 \%$ and $53 \%$ of the watersheds were thinned in the Yarragil $4 \mathrm{X}$ and Yarragil $6 \mathrm{C}$ forests in 2001/2002 respectively, which led to an increase in groundwater recharge, there were no significant effects of thinning either on groundwater or annual streamflow as not enough rainfall was obtained afterward leading to a deficit in soil moisture (Kinal and Stoneman 2011).

\subsection{Impacts of a drying climate on forest and water}

As described earlier, there has also been a systematic change in climate over the last 80 years, with this including an increase in mean annual temperature and a reduction in rainfall (e.g., Figure 2). These changes have been used to explain the major changes in streamflow, as seen in Fig. 3. Across the region, a mean reduction in rainfall of around $15-20 \%$ was associated with a decline in runoff of 50\% (Bates et al. 2008; Petrone et al. 2010). The explanation for these changes is the separation of groundwater systems from surface streamflow, and a step-change in system response when the groundwaters and surface streams are disconnected (Kinal and Stoneman 2012). In the case of Kinal and Stoneman (2012), groundwater levels in a $2.73 \mathrm{~km}^{2}$ watershed systematically decreased by between 6 and $11 \mathrm{~m}$ over a 35 year period. Similarly, Petrone et al. (2010) showed that although there were clear relationships between declines in rainfall and runoff from 1950 to 1989, from 1989 to 2008 runoff continued to decline but rainfall did not.

There has clearly been a change in landscape water balance over time, however, whether this can be completely ascribed to climate change or to changes in evapotranspiration in response to management is less clear. For example, Liu et al. (2019) reported that change in vegetation attributes (land cover/use change and growth of vegetation) dominated the decrease in streamflow from 1982 to 2012 in about twothirds of the watersheds in south-western Australia, using the theoretical framework of Budyko (1974). Similarly, Li et al. (2010) examined data from 41 watersheds with up to 19 years of record and found that the most consistent contribution to changes in watershed runoff ratio was the forest density. Eucalypt forests both re-seed and coppice after fire or harvest, with resultant changes in forest structure (Abbott 1984).

Meanwhile, satellite measurements of vegetation indices, such as NDVI, suggest that forest canopies are not reducing in response to the reduction in rainfall (Smettem et al. 2013; Liu et al. 2017) and the forests may presently be relying on deeper water stores especially in the deep kaolinitic regolith. This is certainly consistent with the declining groundwater pressures reported by Kinal and Stoneman (2012) and also of eucalypt plantation responses to drought where those on deep regoliths, and with presumed access to additional soil water, survived drought conditions, whereas trees on shallow soils and with limited soil water storage died (Harper et al. 2009). What is less clear, however, is how soil moisture contents to depth have changed over time in this region. Several recent papers (Brouwers et al. 2013; Evans et al. 2013; Evans and Lyons 2013; Matusick et al. 2013; Walden et al. 2019) have examined the response of the forests of south-western Australia to a drought year during an extended period of reduced rainfall, with increased forest mortality. Rainfall in 2010 was $40-50 \%$ 
below average rainfall and this was associated with mortality of $1.5 \%$ of forest in the surveyed area (Matusick et al. 2013). A feature of these papers is that although they report tree responses to drought there are no associated measurements of regolith depth, soil water, or groundwater responses.

Climate projections for this region indicate that under most emission scenarios temperatures will continue to increase and rainfall will further decrease (McFarlane et al. 2012a). Future streamflow responses have been modeled for different climate change scenarios. The most comprehensive study involved an assessment of 15 climate change models across three different emission scenarios (Barron et al. 2012; McFarlane et al. 2012a; Silberstein et al. 2012) and this suggests a further decrease in water yield. This study, however, does not include changes in evapotranspiration due to changes in vegetation cover caused by drought or fire. Climate change may also result in a change in water balance and an increase forest mortality while increasing temperatures are likely to be associated with more severe fire conditions. Both drought and fire are likely to change rates of evapotranspiration, interception, and thus rainfall/runoff relationships.

\section{Discussion}

The ecohydrological systems of south-western Australia are clearly responsive, albeit with time lags, to changes in water balance driven by both forest management and climate. More broadly, this paper has highlighted three main considerations for the development and implementation of forest management responses applicable to this and other regions: (1) developing an understanding of the underlying mechanisms for the forest's hydrological responses to land use and climate change, (2) the need for treatments to be applied across entire watersheds to engender change, and (3) identifying methods of financing these changes.

\subsection{Understanding of the forest hydrological responses to land use and climate change}

Before new management systems can be devised, it is necessary to have some understanding about the likely trajectory of future climate change, the way the existing vegetation is managed, the consequent new ecohydrologic equilibrium, and the possible response of the vegetation systems. Although it is highly likely that with climate change there will be further significant change in the water balance and continued drying of the regolith, several aspects of the change of water balance have not been resolved, and in particular what will happen when the end point of the current drying trend is reached and regolith is seasonally dried to bedrock. If the forest canopies are currently being maintained by deep soil water stores, there will likely be a further step change when these stores have been depleted, and the forest will rely solely on annual rainfall inputs. There is already evidence of such thresholds in this region, in both stream yield (Ruprecht and Schofield 1989; Petrone et al. 2010) and salinity responses (Ruprecht and Schofield 1991).

Budyko's ecohydrological framework (Smettem et al. 2013; Zhou et al. 2015; Liu et al. 2019) suggests that the forest canopy will revert to a level reflective of drier rainfall conditions as it will not be buffered by stored soil moisture. This may entail a recession of canopies across the forest and episodic deaths in response to extreme temperature events. More recently, these deaths have occurred in areas where soil water storage is small (Harper et al. 2009), however, on drying of the regolith, they may extend across the whole landscape. Similarly, stream yields will also reflect diminished annual rainfall. The interactive effects of changes in vegetation cover from drought, temperature changes, disease, and also fire are uncertain and require further investigation, particularly for phreatophytic species. A similar issue relates to the impact of a change from perennial to ephemeral stream flows and the year-round availability of water for animal species (Barron et al. 2012).

Importantly, the specific course of climate change is uncertain, not only in the actual global emissions trajectory that will occur, and the impacts of this radiative forcing on both temperatures and water balance (IPCC 2013), but also the impact of this on runoff as implied by Roderick and Farquhar (2011). There will also be additional interactive effects such as between extremes of temperature and increasing atmospheric carbon dioxide content (e.g., Woldendorp et al. 2008) and possibly changes in pests and pathogens as seen in various forests (Kurz et al. 2008; Seidl et al. 2017) in response to climate change. There is a clear need for ongoing manipulative experimentation, long-term monitoring, and the development and implementation of new management strategies for this landscape.

In addition to climate impacts on forest hydrology, there have also been other transient forest disturbances such as timber harvesting, fire, and mining which led to initial increased streamflow but with significant delays related to the presence or lack of a groundwater discharge area. Over time, streamflow returns to either pre-disturbance levels or may reduce to below pre-disturbance levels.

\subsection{The need for watershed-scale treatments to achieve forest-water benefits}

From this paper, it is quite clear that in south-western Australia, water yield and water quality can be readily manipulated at decadal time-scales through actions that manipulate forest cover and thus water balance, such as forest thinning, deforestation, or reforestation. In each case, a key factor in obtaining a response in either water yield or water quality has been to achieve a sufficient scale of activity (Harper 
et al. 2012), such as seen in the Denmark River watershed in response to both deforestation and reforestation (Fig. 4, Ruprecht et al. 2019). In this watershed, reforestation improved water quality to the extent that it was potable, but reduced stream yield.

\subsection{Identifying methods of financing watershed-scale changes}

Obtaining this scale of activity requires financing either from Government subsidies or private investment. In the case of the Denmark River widespread reforestation came from private pulpwood plantation investment. Attempts have been made to emulate this in other watersheds with programs that encourage reforestation such as with carbon mitigation investment (Harper et al. 2012; Harper et al. 2017) however a stable carbon market has not developed in Australia.

One surprising feature, however, is that although forest management activities have had direct impacts on water supplies, the value of this water has not been explicitly brought to account. Thus, no allowance is made for the deleterious effects of deforestation on water quality (Townsend et al. 2012), although this has compromised major water resources such as the 184 GL capacity of Wellington Dam and several other rivers. Similarly, there are no direct rewards for the increase in water quality following broad-scale reforestation or the increase in water yield following forest thinning. Indeed, in some cases, the water values from reforestation may be in excess of the values from timber or agriculture (e.g., Townsend et al. 2012). The marginal cost of water from desalination is around AUD\$1.50-2.00/kL and it could be argued that this provides a basis for valuing water from forest management activities.

There is thus a flaw in the approach of seeking a water benefit from forest management activities as an unvalued cobenefit, rather than as a direct benefit. This lack of value for the water may have several implications. For example, plantation eucalypt yields have been poor in some areas where reforestation has improved water quality and the plantations may be removed and revert to farmland with future water quality highly likely to again deteriorate, as seen with previous deforestation in the Denmark River watershed (Fig. 4). Similarly, although forest thinning has been associated with an increase in water yield, a lack of payment for this water has resulted in limited treatment of watersheds.

What is required is a process where the impacts on water values from both deforestation and reforestation are brought to account and these values were considered as part of the total value of the forestry or agricultural enterprise. The payments could be sourced both from penalties from land that is contributing salts (and other pollutants) into streams and also from sales to water service providers where the value of the water is less than the cost of desalination.
Using an ecosystem service approach to manage forest water and other environmental values has precedence in this (Townsend et al. 2012) and other regions (Deal and White 2012). For the jarrah forest, such an approach could include consideration of provisioning (e.g., here water, wood products, and biodiversity), regulating (e.g., carbon), and cultural ecosystem products (e.g., ecotourism). It is clear, however, that a full stand-alone analysis of the utility of an ecosystems approach, in this region, is required. This would consider existing legislative frameworks, community acceptance of the ecosystems approach (e.g., through forest thinning to increase water yield) and the state of the different ecosystem markets. That said, there has been some discussion of components of this approach in the region in terms of the efficiencies in water use from water markets for groundwater management (Skurray et al. 2013; Bennett and Gardner 2014) and carbon mitigation (Mitchell et al. 2012; Harper et al. 2017).

\subsection{What happens when forest management and water supply are decoupled?}

Although water in south-western Australia has been traditionally obtained from forested watersheds and the forests were maintained primarily for their water resource and timber values, the advent of desalination and groundwater abstraction has resulted in a decoupling of the forest-water nexus. What this means is that forest management is now not seen as critical or significant to supplying water to Perth and raises the question as to what is the likely outcome of this occurrence.

In parallel with the change in water sources has been the reduction in public acceptance of timber extraction from natural forests and a consequent change in land tenure to nonproduction status (Conservation Commission of Western Australia 2013). Thus, two major economic values, water and timber, have been removed.

The forests, however, are still important in terms of their ecological services, such as carbon storage (Walden et al. 2019) and maintenance of wildlife habitat (Daily and Ellison 2002). They also provide social and cultural benefits such as recreation, traditional resource uses, and spirituality. To maintain these values, a new approach to forest management is required. This will involve managing forest values in the context of a changing climate and associated impacts of tree deaths and drying river environments. Decisions need to be made as to what forest environment values can be protected or achieved and how the maintenance of these values is to be funded.

Considering water as a forest product that attracts payments will provide funds for watershed-scale interventions. This could occur within a broader payment for environmental services (PES) framework, encompassing provisioning (e.g., water as well as wood products and biodiversity), regulating 
(e.g., carbon), and cultural ecosystem products. This paper has demonstrated that it is technically possible to manage the forests to increase water flow and improve water quality, howev$\mathrm{er}$, the value of this water is currently not brought to account.

\section{Conclusions}

This paper has shown that it is possible to manipulate watershed water balances through management interventions, thus the question arises whether the transition to a different ecohydrological state is passively or actively managed. This is also the dilemma that will face forest managers in other regions who are attempting to manage climate change.

The forest environment in south-western Australia has changed significantly over the last century and is likely to change in the future in response to climate change. There are two broad options for future management: (a) a passive approach where with minimal intervention the forest finds a new equilibrium, with consequential impacts on biodiversity and other values, or (b) active management where treatments are applied at scale to provide water both for the environment and human use. The latter will require methods of explicitly valuing the forest water resources and their environmental co-benefits, particularly now that non-forest sources of water are being used to meet human demands.

A passive approach will result in the forest adjusting to the new water balance, with impacts on both forest composition and particularly in stream zones as streamflow becomes ephemeral. Active management will entail forest thinning, however, for this to have an effect on landscape hydrology, it will need to be undertaken at scale and this will require significant funding. The lack of a payment system for water means that a potential source of finance does not currently exist and it is thus unlikely that an adequate scale of funding will be available to manage forests for biodiversity values. Our examples of watershed restoration show that broadscale landscape intervention does result in hydrological change, but will not occur as a result of direct public payments. Thus, a priority is to evaluate whether payments for water within a payment for ecosystems services framework will be useful in the future management of these forests.

Acknowledgements We thank Prof. Ray Froend and Dr. Scott Strahan for inputs to an earlier version of this paper and Adj. Assoc. Prof. John McGrath and Adj. Prof. Frank Batini for useful discussions.

Statement on data availability Data are all available in the public domain.

\section{Compliance with ethical standards}

Conflict of interest The author declares that there is no conflict of interest.

\section{References}

Abbott I (1984) Comparisons of spatial pattern, structure, and tree composition between virgin and cut-over jarrah forest in Western Australia. For Ecol Manag 9:101-126

ABS (2016) Australian demographic statistics; September quarter 2015. Australian Bureau of Statistics, Canberra

Allen CD, Macalady AK, Chenchouni H, Bachelet D, McDowell N, Vennetier M, Kitzberger T, Rigling A, Breshears DD, Hogg EH, Gonzalezk P, Fensham R, Zhang Z, Castro J, Demidova N, Lim J, Allard G, Running SW, Semerci A, Cobb N (2010) A global overview of drought and heat-induced tree mortality reveals emerging climate change risks for forests. For Ecol Manag 259:660-684

Anand RR, Paine M (2002) Regolith geology of the Yilgarn Craton, Western Australia: implications for exploration. Australian Journal of Earth Sciences 49:3-162. https://doi.org/10.1046/j.1440-0952. 2002.00912.x

Bari MA, JK Ruprecht (2003) Water yield response to land use change in south-west Western Australia. Salinity and Land Use Impacts Series, Report SLUI 31. Department of Environment, Perth

Bari MA, Smettem KRJ (2006) A conceptual model of daily water balance following partial clearing from forest to pasture. Hydrol Earth Syst Sci 10:321-337

Bari MA, GW Mauger, RNM Dixon, LH Boniecka, B Ward, T Sparks, AM Waterhouse (2004) Salinity situation statement Denmark River. Water Resource Technical Series Report No. WRT 30, Department of Environment, Perth

Barron O, Silberstein RP, Ali R, Donohue R, McFarlane DJ, Davies P, Hodgson G, Smart N, Donn M (2012) Climate change effects on water-dependent ecosystems in south-western Australia. J Hydrol 434-435:95-109

Bartle JR, Shea S (1989) Development of a pulpwood cropping industry in Western Australia. Land and Water Research News 1:5-9

Bates BC, Hope P, Ryan B, Smith I, Charles S (2008) Key findings from the Indian Ocean Climate Initiative and their impact on policy development in Australia. Clim Chang 89:339-354. https://doi.org/10. 1007/s10584-007-9390-9

Bennett M, Gardner AW (2014) Groundwater regulation in a drying south west. UWA Faculty of Law Research Paper 2014-42. The University of Western Australia, Perth, p 150

Brouwers N, Matusick G, Ruthrof K, Lyons T, Hardy G (2013) Landscape-scale assessment of tree crown dieback following extreme drought and heat in a Mediterranean eucalypt forest ecosystem. Landsc Ecol 28:69-80. https://doi.org/10.1007/s10980-0129815-3

Budyko M (1974) Climate and life. Cambridge University Press, Cambridge, U.K.

Bureau of Meteorology (2018) Average annual, monthly and seasonal evaporation. http://www.bom.gov.au/jsp/ncc/climate_averages/ evaporation/index.jsp. Accessed 29 Aug. 2018

Burvill GH (1979) The development of light lands. In: Burvill GH (ed) Agriculture in Western Australia. University of Western Australia Press, Nedlands, pp 157-172

Conservation Commission of Western Australia (2013) Forest management plan 2014-2023. Conservation Commission of Western Australia, Perth

Country Areas Water Supply Act Amendment Act (1976), Government of Western Australia, Perth

Country Areas Water Supply Act Amendment Act (1978), Government of Western Australia, Perth

Croton JT, Dalton JA (1999) Stream salinity response to clearing and revegetation of the Helena catchment. Water and environmental consultants internal report to the Water and Rivers Commission, Perth 
Daily GC, Ellison K (2002) The new economy of nature: the quest to make conservation profitable. Island Press, Washington

Deal RL, White R (2012) Integrating forest products with ecosystem services: a global perspective. For Policy Econ 17:1-2

Dell B, Bartle JR, Tacey WH (1983) Root occupation and root channels of jarrah forest subsoils. Aust J Bot 31:615-627

Dell D, Havel JJ, Malajczuk N (eds) (1989) The jarrah Forest: a complex Mediterranean ecosystem. Kluwer, Dordrecht

Evans BJ, Lyons T (2013) Bioclimatic extremes drive forest mortality in southwest, Western Australia. Climate 1:28-52. https://doi.org/10. 3390/cli1020028

Evans B, Stone C, Barber P (2013) Linking a decade of forest decline in the south-west of Western Australia to bioclimatic change. Aust For 76:164-172. https://doi.org/10.1080/00049158.2013.844055

Garcia-Ruiz J, Lopez-Moreno J, Vicente-Serrano S, Lasanta-Martinez T, Begueria S (2011) Mediterranean water resources in a global change scenario. Earth Sci Rev 105:121-139

George RJ, Nulsen RA, Ferdowsian R, Raper GP (1999) Interactions between trees and groundwaters in recharge and discharge areas a survey of Western Australian sites. Agric Water Manag 39:91-113

Giglio L, Randerson J, van der Werf G (2013) Analysis of daily, monthly, and annual burned area using the fourth-generation global fire emissions database (GFED4). J Geophys Res 118:317-328

Harper RJ, Smettem KRJ, Carter JO, McGrath JF (2009) Drought deaths in Eucalyptus globulus (Labill.) plantations in relation to soils, geomorphology and climate. Plant Soil 324:199-207. https://doi.org/ 10.1007/S11104-009-9944-X

Harper RJ, Smettem KRJ, Townsend PV, Bartle JR, McGrath JF (2012) Broad-scale restoration of landscape function with timber, carbon and water investment. In: Stanturf JA, Lamb D, Madsen P (eds) Forest landscape restoration: integrating social and natural sciences. Springer, New York, pp 275-292

Harper RJ, Sochacki SJ, McGrath JF (2017) The development of reforestation options for dryland farmland in South-Western Australia: a review. Southern Forests 79:185-196. https://doi.org/10.2989/ 20702620.2016.1255417

Hatton TJ, Ruprecht J, George RJ (2003) Preclearing hydrology of the Western Australian wheatbelt: target for the future? Plant Soil 257: 341-356

Hingston FJ, Gailitis V (1976) The geographic variation of salt precipitated over Western Australia. Aust J Soil Res 14:319-335

IPCC (2012) Summary for policy makers. Managing the risks of extreme events and disasters to advance climate change adaptation. A Special Report of Working Groups I and II of the Intergovernmental Panel on Climate Change. Cambridge University Press, Cambridge and New York

IPCC (2013) Climate change 2013: the physical science basis. Contribution of Working Group I to the Fifth Assessment Report of the Intergovernmental Panel on Climate Change. Cambridge University Press, Cambridge and New York

Johnstone CD (1981) Salt contents of soil profiles in bauxite mining areas of the Darling Range, Western Australia. Land Resources Management Technical Paper No. 8. CSIRO Australia, Melbourne

Kinal J, Stoneman GL (2011) Hydrological impact of two intensities of timber harvest and associated silviculture in the jarrah forest in south-western Australia. J Hydrol 399:108-120

Kinal J, Stoneman GL (2012) Disconnection of groundwater from surface water causes a fundamental change in hydrology in a forested catchment in south-western Australia. J Hydrol 472:14-24. https://doi. org/10.1016/j.jhydrol.2012.09.013

Koch JM, Hobbs RJ (2007) Synthesis: is Alcoa successfully restoring a jarrah forest ecosystem after bauxite mining in Western Australia? Restor Ecol 15:S137-S144. https://doi.org/10.1111/j.1526-100X. 2007.00301.x

Kurz WA, Dymond CC, Stinson G, Rampley GJ, Neilson ET, Carroll AL, Ebata T, Safranyik L (2008) Mountain pine beetle and forest carbon feedback to climate change. Nature 452:987-990. https://doi.org/10. 1038/nature06777

Li M, Wallace J, Campbell E (2010) Forest change and water yield response: a statistical data integration analysis. Water for a Healthy Country Flagship Report. CSIRO, Canberra

Little C, Lara A, McPhee J, Urrutia R (2009) Revealing the impact of forest exotic plantations on water yield in large scale watersheds in South-Central Chile. J Hydrol Hi 374:162-170

Liu N, RJ Harper B, Dell S, Liu ZY (2017) Vegetation dynamics and rainfall sensitivity for different vegetation types of the Australian continent in the dry period 2002-2010. Ecohydrology 10:e1811. https://doi.org/10.1002/eco.1811

Liu N, RJ Harper, KRJ Smettem, B Dell, S Liu (2019) Responses of streamflow to vegetation and climate change in southwestern Australia. J Hydrol 572:761-770. https://doi.org/10.1016/j.jhydrol. 2019.03.005

Lutz S, Mallucci S, Diamantini E, Majone B, Bellin A, Merz R (2016) Hydroclimatic and water quality trends across three Mediterranean river basins. Sci Total Environ 571:1392-1406

Matusick G, Ruthrof KX, Brouwers NC, Dell B, Hardy GSJ (2013) Sudden forest canopy collapse corresponding with extreme drought and heat in a Mediterranean-type eucalypt forest in southwestern Australia. Eur J For Res 132:497-510. https://doi.org/10.1007/ s10342-013-0690-5

Mauger GW, Bari M, Boniecka L, Dixon RNM, Dogramaci SS, Platt J (2001) Salinity situation statement Collie River. Water Resources Commission, Water Resource Technical Report WRT 29:108

McArthur WM (1991) Reference soils of south-western Australia. Australian Society of Soil Science Inc. (WA Branch), Perth

McCaw WL, Burrows ND (1989) Fire management. In: Dell B, Havel JJ, Malajczuk N (eds) The jarrah forest - a complex Mediterranean ecosystem. Kluwer Academic Publishers, Dordrecht, pp 317-334

McFarlane D, Stone R, Martens S, Thomas J, Silberstein R, Ali R, Hodgson G (2012a) Climate change impacts on water yields and demands in south-western Australia. J Hydrol 475:488-498. https:// doi.org/10.1016/j.jhydrol.2012.05.038

McFarlane D, Strawbridge M, Stone R, Paton A (2012b) Managing groundwater levels in the face of uncertainty and change: a case study from Gnangara. Water Sci Technol Water Supply 12:321328. https://doi.org/10.2166/ws.2011.137

Milly P, Dunne K, Vecchia A (2005) Global pattern of trends in streamflow and water availability in a changing climate. Nature 438:347-350

Mitchell CD, Harper RJ, Keenan RJ (2012) Status and prospects of carbon forestry in Australia. Aust For 75:200-212. https://doi.org/10. 1080/00049158.2012.10676402

Myers JS (1990) Western gneiss terrane, in Geology and Mineral Resources of Western Australia, Memoir No. 3. Western Australia Geological Survey, Perth. pp 13-32

National Health and Medical Research Council (2004) Australian drinking water guidelines (6) - national water quality management strategy. National Health and Medical Research Council, Canberra

Parsons M, Gavran M (2010) Australia's plantations 2010 inventory update. National Forest Inventory, Bureau of Rural Sciences, Canberra, p 8

Peck AJ, Hatton TJ (2003) Salinity and the discharge of salts from catchments in Australia. J Hydrol 272:191-202

Peck AJ, Hurle DH (1973) Chloride balance of some farmed and forested catchments in southwestern Australia. Water Resour Res 9:648-657

Peck AJ, Williamson DR (1987) Effects of forest clearing on groundwater. J Hydrol 94:47-65

Peñuelas J, Sardans J, Filella I, Estiarte M, Llusià J, Ogaya R, Carnicer J, Bartrons M, Rivas-Ubach A, Grau O, Peguero G, Margalef O, PlaRabés S, Stefanescu C, Asensio D, Preece C, Liu L, Verger A, Barbeta A, Achotegui-Castells A, Gargallo-Garriga A, Sperlich D, Farré-Armengol G, Fernández-Martínez M, Liu D, Zhang C, Urbina 
I, Camino-Serrano M, Vives-Ingla M, BD Stocker M, Balzarolo R, Guerrieri M, Peaucelle S, Marañón-Jiménez K, Bórnez-Mejías ZM, Descals A, Castellanos A, Terradas J (2017) Impacts of global change on Mediterranean forests and their services. Forests 8:463

Petrone KC, Hughes JD, Van Niel TG, Silberstein RP (2010) Streamflow decline in southwestern Australia, 1950-2008. Geophys Res Lett:37

Roderick ML, Farquhar GD (2011) A simple framework for relating variations in runoff to variations in climatic conditions and catchment properties. Water Resour Res 47:W00G07. https://doi.org/10. 1029/2010WR009826

Ruprecht JK, Schofield NJ (1989) Analysis of streamflow generation following deforestation in south-west Western Australia. J Hydrol 105:1-18

Ruprecht JK, Schofield NJ (1991) Effects of partial deforestation on hydrology and salinity in high salt storage landscapes. I. Extensive block clearing. J Hydrol 129:19-38

Ruprecht JK, Stoneman GL (1993) Water yield issues in the jarrah forest of south-western Australia. J Hydrol 150:369-391

Ruprecht JK, RA Stokes, RB Pickett (1985) Denmark River yield and salinity study. Hydrology Branch Report No. WH8. Water Authority of Western Australia, Perth

Ruprecht JK, Schofield NJ, Crombie DS, Vertessy RA, Stoneman GL (1991) Early hydrological response to intense forest thinning in southwestern Australia. J Hydrol 127:261-277

Ruprecht JK, T Sparks, N Liu, B Dell, Harper RJ (2019) Using reforestation to reverse salinisation in a large watershed. J Hydrol 577. https://doi.org/10.1016/j.jhydrol.2019.123976

Sadler BS, Mauger GW, Stokes RA (1988) The water resource implications of a drying climate in south-west Western Australia. In: Pearman GI (ed) Greenhouse: planning for climate change. E.J. Brill, Leiden, pp 296-311

Seidl R, Thom D, Kautz M, Martin-Benito D, Peltoniemi M, Vacchiano G, Wild J, Ascoli D, Petr M, Honkaniemi J, Lexer MJ, Trotsiuk V, Mairota P, Svoboda M, Fabrika M, Nagel TA, Reyer CPO (2017) Forest disturbances under climate change. Nat Clim Chang 7:395402. https://doi.org/10.1038/nclimate3303

Shea SR, Bartle JR (1988) Restoring nature's balance: the potential for major reforestation of south western Australia. Landscope 3:3-14

Silberstein RP, Aryal SK, Durrant J, Pearcey M, Braccia M, Charles SP, Boniecka L, Hodgson GA, Bari MA, Viney NR, McFarlane DJ (2012) Climate change and runoff in south-western Australia. J Hydrol 475:441-455. https://doi.org/10.1016/j.jhydrol.2012.02.009

Skurray JH, Pandit R, Pannell DJ (2013) Institutional impediments to groundwater trading: the case of the Gnangara groundwater system of Western Australia. J Environ Plan Manag 56:1046-1072

Smettem KRJ, Waring RJ, Callow J, Wilson M, Mu Q (2013) Satellite derived estimates of forest leaf area index in south-west Western Australia are not tightly coupled to inter-annual variations in rainfall: implications for groundwater decline in a drying climate. Glob Change Biol 19:2401-2412. https://doi.org/10.1111/gcb.12223

Smith R (1950) The classification of virgin lands from soil surveys, south-western Australia. Transactions 4th International Congress Soil Science, Amsterdam, pp 370-373

Smith M, R Dixon, L Boniecka, M Berti, T Sparks, M Bari, J Platt (2006) Salinity situation statement Warren River. Water Resource Technical Series Report No. WRT 32
Smith RA, MA Bari, RNM Dixon, DW Rowlands (2007) Helena River salinity situation statement. Water Resource Technical Series Report No. WRT 34. Department of Water, Perth

Stokes RA, FE Batini (1985) Streamflow and groundwater responses to logging in Wellbucket Catchment, south western Australia. Surface Water Branch Report No. WH3. Water Authority of Western Australia, Perth

Stoneman GL (1993) Hydrological response to thinning a small jarrah (Eucalyptus marginata) forest catchment. J Hydrol 150:393-407

Stoneman GL, Schofield NJ (1989) Silviculture for water production in jarrah forest of Western Australia: an evaluation. For Ecol Manag 27:273-293. https://doi.org/10.1016/0378-1127(89)90111-4

Stoneman GL, Bradshaw FJ, Christensen P (1989) Silviculture. In: Dell B, Havel JJ, Malacjzuk N (eds) The jarrah forest - a complex Mediterranean ecosystem. Kluwer Academic Publishers, Dordrecht, pp 335-355

State Salinity Strategy (1996) Salinity: a situation statement for Western Australia. A report to the Minister of Primary Industry and the Minister for the Environment. Government of Western Australia, Perth

Taylor G, Butt CRM (1998) The Australian regolith and mineral exploration. AGSO J Aust Geol Geophys 17:55-67

Townsend PV, Harper RJ, Brennan PD, Dean C, Wu S, Smettem KRJ, Cook SE (2012) Multiple environmental services as an opportunity for watershed restoration. For Policy Econ 17:45-58

Tsykin EN, Slessar GC (1985) Estimation of salt storage in the deep lateritic soils of the Darling Plateau, Western Australia. Aust J Soil Res 23:533-541

Walden LL, Fontaine JB, Ruthrof KX, Matusick G, Harper RJ, Hardy GE (2019) Forest carbon dynamics following global-change-type drought. Glob Change Biol 25:1653-1664

Water Corporation (2009) Water forever: towards climate resilience. Water Corporation, Perth

Water Corporation (2015) 2015 annual report of the Water Corporation. www.watercorporation.com.au/-/media/files/residential/about-us/ our-performance/annual-report-2015/water-corporation-annualreport-2015.pdf. Accessed 3 Aug 2018

Western Australian Planning Commission (2015) Perth and Peel@3.5million. Western Australian Planning Commission, Perth

Williamson DR, Stokes RA, Ruprecht JK (1987) Response of input and output of water and chloride to clearing for agriculture. J Hydrol 94: $1-28$

Woldendorp G, Hill MJ, Doran R, Ball MC (2008) Frost in a future climate: modelling interactive effects of warmer temperatures and rising atmospheric [CO2] on the incidence and severity of frost damage in a temperate evergreen (Eucalyptus pauciflora). Glob Change Biol 14:294-308

Wood WE (1924) Increase of salt in soil and streams following destruction of the native vegetation. J R Soc West Aust 10:35-47

Zhou G, Wei X, Chen X, Zhou P, Liu X, Xiao Y, Sun G, DF Scott S, Zhou L, Han YS (2015) Global pattern for the effect of climate and land cover on water yield. Nat Commun 6:5918. https://doi.org/10.1038/ ncomms6918

Publisher's note Springer Nature remains neutral with regard to jurisdictional claims in published maps and institutional affiliations. 